\title{
Simulation of Supercritical Water Gasification of Microalgae for Hydrogen and Methane-rich Gas Production
}

\author{
Sherif Ishola Mustapha, Usman Aliyu Mohammed, Faizal Bux and Yusuf Makarfi Isa
}

\begin{abstract}
The supercritical water gasification of Nannochloropsis sp, Spirulina sp. and Scenedesmus obliquus microalgae was examined using Aspen plus (V11) software. The influence of temperature $\left(400-700{ }^{\circ} \mathrm{C}\right)$ and biomass concentration $(10$ $-40 \mathrm{wt} \%$ ) on the composition, yield and lower heating value (LHV) of the gaseous product was investigated. The results showed that low temperature and high biomass concentration favors the production of methane-rich gas while high temperature and low biomass concentration favors hydrogen-rich gas production. Higher $\mathrm{CH}_{4}$ yield was observed at biomass concentration of $40 \mathrm{wt} \%$ which is an indication that the methanation reaction is accelerated at higher biomass concentration. The ranking order for the $\mathrm{H}_{2}$ and $\mathrm{CH}_{4}$ yield is Nannochloropsis sp> Scenedesmus obliquus> Spirulina sp. The highest LHV of $18.97 \mathrm{MJ} / \mathrm{kg}, 15.86 \mathrm{MJ} / \mathrm{kg}$ and $18.49 \mathrm{MJ} / \mathrm{kg}$ was obtained for Nannochloropsis sp., Spirulina sp. and Scenedesmus obliquus respectively at temperature of $400{ }^{\circ} \mathrm{C}$ and biomass concentration of $40 \mathrm{wt} \%$.
\end{abstract}

Keywords - Supercritical water gasification, microalgae, methane, hydrogen.

\section{INTRODUCTION}

Hydrogen and methane are regarded as important components of the future world clean energy portfolio [1, 2]. Supercritical water gasification (SCWG) has the potential to produce high-quality methane-rich and hydrogen-rich gas especially from wet algal biomass without the need for drying the biomass [3]. The factors that could influence the gas yields and compositions include biomass feedstock composition, biomass concentration, gasification temperature, gasification pressure, and residence time $[4,5]$. So far, this technique is seen as a more promising gasification pathway for high-moisture-containing biomasses such as microalgae. However, the effect of the factors that could influence the

Manuscript received September 10, 2020.

*Sherif Ishola Mustapha is with Fuels and Petrochemicals Group, Department of Chemical Engineering, Durban University of Technology, Durban 4000, South Africa.

Usman Aliyu Mohammed is with Fuels and Petrochemicals Group, Department of Chemical Engineering, Durban University of Technology, Durban 4000, South Africa.

Faizal bux is with Institute for Water and Wastewater Technology, DUT, P.O. Box 1334, Durban 4000, South Africa.

Yusuf Makarfi Isa is with Fuels and Petrochemicals Group, Department of Chemical Engineering, Durban University of Technology, Durban 4000, South Africa. supercritical water gasification efficiency needs to be well understood for the development of optimal processing technique.

The experimental works on supercritical water gasification are time-consuming and expensive in terms of investment cost and consumable materials [6,7]. Hence, it is necessary to develop a thermodynamic model to simulate the process behavior to save time and resources. Thermodynamic equilibrium model analysis is faster, economically more attractive and can be applied to determine the optimum experimental operating conditions with high accuracy [5]. Till date, only a few studies have been reported on the gasification of microalgae under supercritical water condition. There is a dearth of modelling work on supercritical water gasification of microalgae using Aspen Plus or any other simulation software. This study presents the thermodynamic modelling and simulation of the supercritical water gasification of various microalgae biomass using Aspen Plus. The effect of varying feedstock composition, temperature and biomass concentration on the composition and yield of the gaseous product were investigated and optimum conditions established.

\section{MATERIALS AND METHOD}

Fig. 1 shows the Aspen flow sheet for the supercritical water gasification process. Three different microalgae biomass were considered in this study. The Scenedesmus obliquus microalgae was collected from the Institute of water and wastewater technology, Durban University of Technology, Durban, South Africa and characterized for its proximate and ultimate analysis. While Nannochloropsis sp. [11] and Spirulina sp. [12] were from previous work. The properties of the three microalgae biomass are presented in Table 1. The supercritical water gasification simulation model was developed based on Gibbs free energy minimization using Aspen Plus (Version 11). The simulation methodology reported by [8] was adopted. The list of components added to the simulation includes hydrogen, nitrogen, oxygen, sulfur, carbon monoxide, carbon dioxide, methane, water, ammonia, hydrogen sulfide, solid carbon, and non-conventional biomass and ash. The non-conventional components are modelled by their proximate and ultimate analyses. The Peng-Robinson with Boston-Mathias function (PR-BM) property method was considered for this simulation as it provides good accuracy for gasification simulations $[6,9,10]$. The supercritical water gasification process is simulated using the RYield and RGibbs block as shown in Fig.1. All the 
assumptions made by Atikah and Harun [8] was also considered in this simulation.

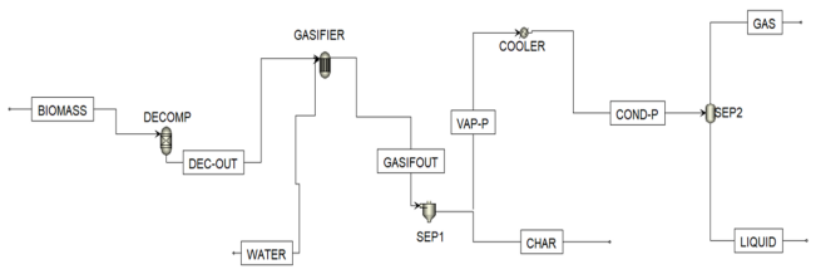

Fig 1. Aspen flow sheet for the supercritical water gasification process

TABLE 1: FEEDSTOCK COMPOSITION FOR THE HYDROTHERMAL GASIFICATION PROCESS

\begin{tabular}{cccc}
\hline \hline & Nannochloropsis sp. & Spirulina sp. & $\begin{array}{c}\text { Scenedesmus } \\
\text { obliquus }\end{array}$ \\
\hline Moisture & Proximate Analysis (\%) & \\
Ash & 5.00 & 8.45 & 4.38 \\
Volatile matter & 5.03 & 13.99 & 10.17 \\
Fixed carbon & 79.69 & 65.48 & 81.77 \\
& 10.28 & 12.08 & 3.68 \\
C & Ultimate Analysis (\%) & \\
H & 49.07 & 39.26 & 45.03 \\
N & 7.59 & 6.11 & 7.50 \\
S & 6.29 & 6.65 & 3.59 \\
O & 1.42 & 0.57 & 0.98 \\
\hline \hline
\end{tabular}

\section{RESULTS AND DISCUSSION}

\section{A. Effect of Temperature on the Composition and Yield of Gaseous Product}

Fig. 2 shows the effect of temperature on the composition of hydrogen and methane gas obtained from the supercritical water gasification of Nannochloropsis sp., Spirulina sp. and Scenedesmus obliquus microalgae biomass. The temperature was varied between $400{ }^{\circ} \mathrm{C}$ and $700{ }^{\circ} \mathrm{C}$ at pressure of $30 \mathrm{MPa}$ and biomass concentration of $10 \mathrm{wt} \%$. As shown in Fig. 2, the composition of $\mathrm{H}_{2}$ increased while the $\mathrm{CH}_{4}$ composition decreased in all the three microalgae biomass as the temperature was increased from $400{ }^{\circ} \mathrm{C}$ to $700{ }^{\circ} \mathrm{C}$. The three major reactions identified to be responsible for the production of gaseous products during supercritical water gasification process include steam reforming, water-gas shift reaction and methanation [1, 13]. The steam reforming and water-gas shift reactions are responsible for the $\mathrm{H}_{2}$ production while methanation reaction is responsible for $\mathrm{CH}_{4}$ production. Methanation and water-gas shift reaction are exothermic reaction usually favored at low temperature. On the other hand, the steam reforming reaction is endothermic favoring the production of hydrogen at higher temperature. The low $\mathrm{H}_{2}$ composition observed at $400{ }^{\circ} \mathrm{C}$ is majorly from the water-gas shift reaction and the $\mathrm{H}_{2}$ composition increased significantly for all the microalgae biomass as the temperature was increased due to steam reforming reactions which is favored at higher temperature. On the contrary, higher composition of $\mathrm{CH}_{4}$ was observed at $400{ }^{\circ} \mathrm{C}$ and subsequent increase in temperature resulted in decrease of $\mathrm{CH}_{4}$ composition possibly due to the methanation reaction favored at low temperature.

When the performance of the different microalgae biomass was compared as the temperature was increased from 400 to 700 ${ }^{\circ} \mathrm{C}$, the $\mathrm{H}_{2}$ composition increased from 4.45 to $50.235 \%, 5.20$ to $53.845 \%$ and 4.84 to $52.60 \%$ while $\mathrm{CH}_{4}$ composition decreased from 49.84 to $12.55 \%, 41.23$ to $5.98 \%$ and 48.55 to $10.19 \%$ for Nannochloropsis sp, Spirulina sp. and Scenedesmus obliquus respectively. The ranking order for the $\mathrm{H}_{2}$ composition is Spirulina sp.> Scenedesmus obliquus $>$ Nannochloropsis $\mathrm{sp.}$ while the ranking order for $\mathrm{CH}_{4}$ composition is Nannochloropsis $\mathrm{sp}>$ Scenedesmus obliquus $>$ Spirulina $\mathrm{sp}$. The difference in the $\mathrm{H}_{2}$ and $\mathrm{CH}_{4}$ composition could result from the variation in the microalgae biomass composition. Nannochloropsis sp with the higher lipid content gave the highest composition of $\mathrm{CH}_{4}$ while $\mathrm{H}_{2}$ composition was more favored with Spirulina sp. having higher carbohydrate content. Also, the degradation of the long-chain fatty acids present in lipids could be responsible for the high yield of $\mathrm{CH}_{4}$ gas [1]. Some previous have also reported have also reported that the presence of protein and carbohydrate could favor $\mathrm{H}_{2}$ production $[13,14]$.

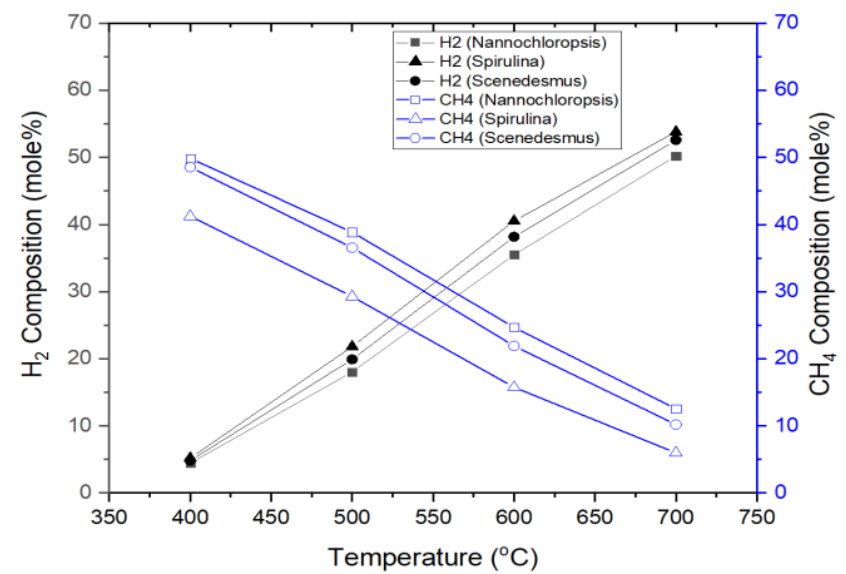

Fig. 2. Effect of temperature on $\mathrm{H}_{2}$ and $\mathrm{CH}_{4}$ gas composition (pressure: $30 \mathrm{MPa}$, biomass concentration: $10 \mathrm{wt} \%$ )

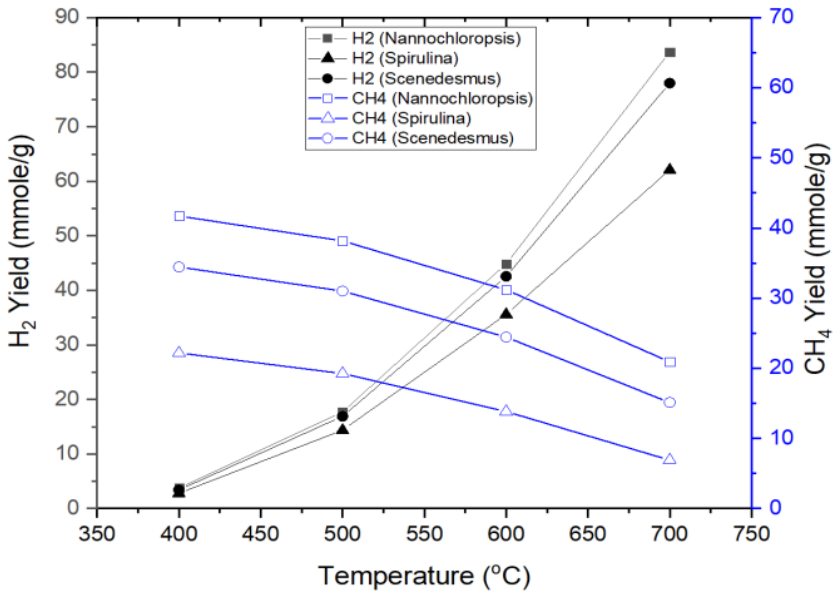

Fig. 3. Effect of temperature on $\mathrm{H}_{2}$ and $\mathrm{CH}_{4}$ gas yield (pressure: 30 $\mathrm{MPa}$, biomass concentration: $10 \mathrm{wt} \%$ )

In a similar manner, the yield of $\mathrm{H}_{2}$ produced was found to increase while $\mathrm{CH}_{4}$ yield decreased as the temperature was 
increased from $400{ }^{\circ} \mathrm{C}$ to $700{ }^{\circ} \mathrm{C}$ as shown Fig. 3. The $\mathrm{H}_{2}$ yield increased from 3.73 to $83.71 \mathrm{mmole} / \mathrm{g}, 2.80$ to $62.09 \mathrm{mmol} / \mathrm{g}$ and 3.43 to $77.98 \mathrm{mmole} / \mathrm{g}$ while $\mathrm{CH}_{4}$ yield decreased from 41.71 to $20.92 \mathrm{mmole} / \mathrm{g}, 22.18$ to $6.90 \mathrm{mmole} / \mathrm{g}$ and 34.43 to $15.11 \mathrm{mmole} / \mathrm{g}$ for Nannochloropsis sp, Spirulina sp. and Scenedesmus obliquus respectively. The ranking order for the $\mathrm{H}_{2}$ and $\mathrm{CH}_{4}$ yield is Nannochloropsis sp> Scenedesmus obliquus $>$ Spirulina sp. Although Spirulina sp. gave the highest $\mathrm{H}_{2}$ composition of $53.84 \%$, however, the $\mathrm{H}_{2}$ yield (62.09 mmole/g) under the same condition was found to be the lowest when compared to Nannochloropsis sp. (83.71 mmole/g) and Scenedesmus obliquus $(77.98 \mathrm{mmole} / \mathrm{g})$. The high ash content and lower carbon content present in the Spirulina sp. as shown in Table 1 may be responsible for the lower $\mathrm{H}_{2}$ yield. Not only that, Spirulina sp. biomass has the lowest volatile matter content when compared to Nannochloropsis sp. and Scenedesmus obliquus. This is a confirmation that biomass feedstock composition has effect on the product yield and composition under the supercritical water gasification process. Previous study by Atikah and Harun [8]) also reported that $\mathrm{H}_{2}$ production is favored at a higher temperature whereas lower temperature favors $\mathrm{CH}_{4}$ production.

\section{B. Effect of Biomass Concentration on Composition and Yield of Gaseous Product}

The effect of biomass concentration on the gas product yield and composition was examined. The biomass concentration was varied from $10 \mathrm{wt} \%$ to $40 \mathrm{wt} \%$ at pressure of $30 \mathrm{MPa}$ and temperature of $700{ }^{\circ} \mathrm{C}$. Fig 4 and 5 shows the effect of biomass concentration on $\mathrm{H}_{2}$ and $\mathrm{CH}_{4}$ composition and yield respectively. As shown in Fig. 4, the Spirulina sp. microalgae gave the highest composition of $\mathrm{H}_{2}$ at biomass concentration of $10 \mathrm{wt} \%$ while Nannochlopsis sp. microalgae gave the highest $\mathrm{CH}_{4}$ composition at biomass concentration of $40 \mathrm{wt} \%$. For the microalgae biomass, the highest $\mathrm{H}_{2}$ composition was obtained at $10 \mathrm{wt} \%$ and decreased as the biomass concentration was increased to $40 \mathrm{wt} \%$. On the contrary, the lowest $\mathrm{CH}_{4}$ composition was observed at $10 \mathrm{wt} \%$ for the microalgae biomass and increase as the biomass concentration was increased to $40 \mathrm{wt} \%$. Biomass concentration could influence the supercritical water gasification process as water is a reactant for the steam reforming and water-gas shift reactions. At lower biomass concentration, more water is available which could accelerate the steam reforming and water-gas shift reactions thereby favoring more $\mathrm{H}_{2}$ production at lower biomass concentration. In addition, the possibility of the transfer of hydrogen atoms from excess water to the gaseous product during supercritical water gasification process could contribute to the higher $\mathrm{H}_{2}$ production observed at lower biomass concentration. Previous studies on supercritical water gasification also reported higher hydrogen gasification efficiency at lower biomass concentration $[13,15,16]$.

As shown in Fig. 5, Nannochlopsis sp. gave the highest $\mathrm{H}_{2}$ yield $(83.71 \mathrm{mmole} / \mathrm{g})$ at lower biomass concentration of 10 wt $\%$ and highest $\mathrm{CH}_{4}$ yield $(36.78 \mathrm{mmole} / \mathrm{g})$ at higher biomass concentration of $40 \mathrm{wt} \%$. The higher $\mathrm{CH}_{4}$ yield at $40 \mathrm{wt} \%$ is an indication that the methanation reaction is accelerated at higher biomass concentration. These findings agree with previous study by Jiao et al. [13]. The higher $\mathrm{H}_{2}$ yield and $\mathrm{CH}_{4}$ observed with the Nannochlopsis sp. can be attributed to the cumulative effect of low ash content and high lipid content present in the microalgae.

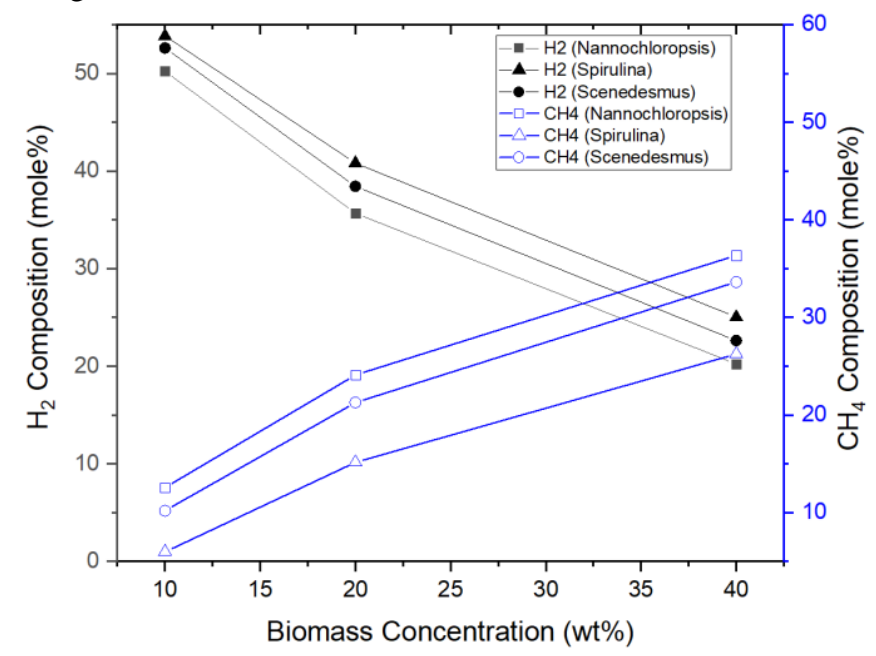

Fig. 4. Effect of biomass concentration on $\mathrm{H}_{2}$ and $\mathrm{CH}_{4}$ gas composition (pressure: $30 \mathrm{MPa}$, temperature: $700{ }^{\circ} \mathrm{C}$ )

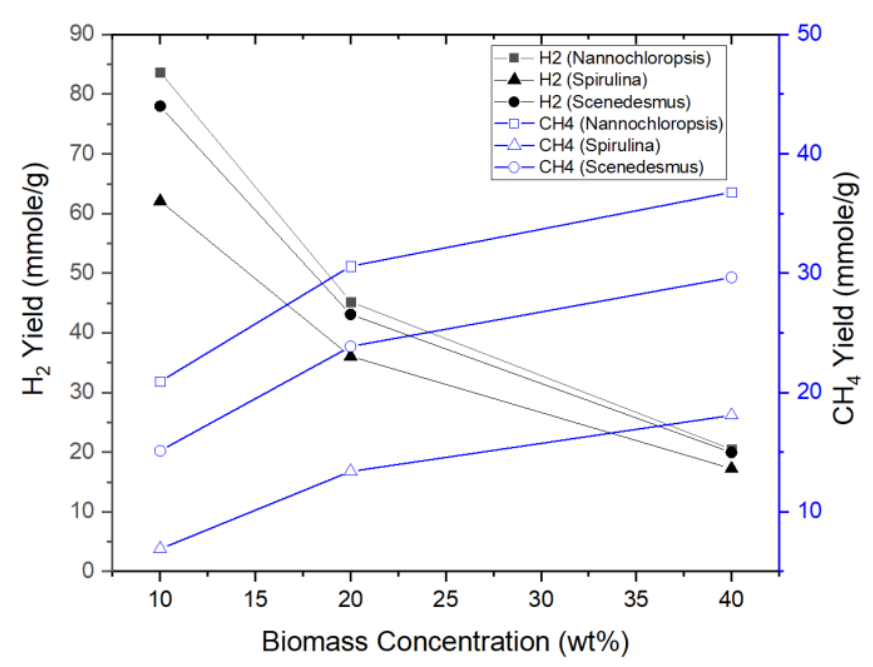

Fig. 5. Effect of biomass concentration on $\mathrm{H}_{2}$ and $\mathrm{CH}_{4}$ gas yield (pressure: $30 \mathrm{MPa}$, temperature: $700{ }^{\circ} \mathrm{C}$ )

\section{Effect of Temperature and Biomass Concentration on Lower Heating Value of Gaseous Product}

The effect of temperature and biomass concentration on the lower heating value (LHV) of the product gas was explored and results presented in Fig. 6. For all the microalgae biomass, the LHV decreases with increase in temperature and the LHV was higher at higher biomass concentration. The highest LHV was observed at temperature of $400{ }^{\circ} \mathrm{C}$ and biomass concentration of $40 \mathrm{wt} \%$. Under these conditions, The LHV of $18.97 \mathrm{MJ} / \mathrm{kg}$, $15.86 \mathrm{MJ} / \mathrm{kg}$ and $18.49 \mathrm{MJ} / \mathrm{kg}$ was observed for Nannochloropsis sp., Spirulina sp. and Scenedesmus obliquus respectively. In terms of ranking order, the LHV of Nannochloropsis $\mathrm{sp}>$ Scenedesmus obliquus $>$ Spirulina sp. for all the temperature and biomass concentration considered. The high LHV observed with the Nannochloropsis sp. could be as a 
result of its high lipid content favoring more of $\mathrm{CH}_{4}$ production which contributed significantly to the high LHV of the product gas.

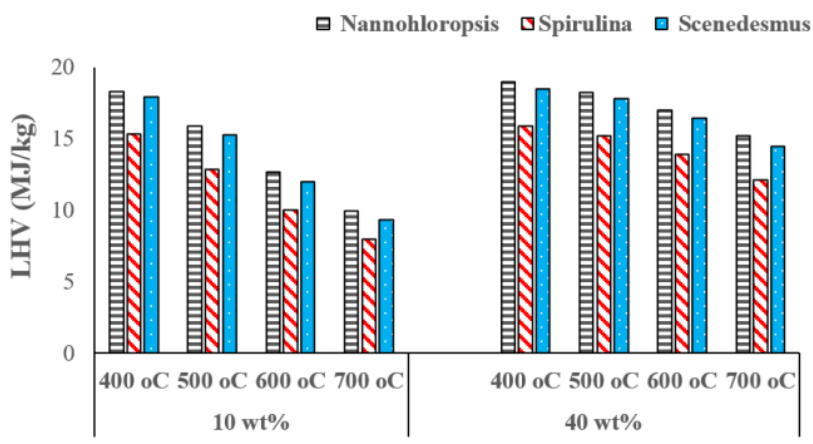

Fig. 6. Effect of temperature at different biomass concentration on the gas mixture lower heating value

\section{CONCLUSION}

This study presents the supercritical water gasification of various microalgae biomass using thermodynamic approach based on Gibbs free energy minimization. Three microalgae biomass which include Nannochloropsis sp., Spirulina sp., and Scenedesmus obliquus with varying composition were considered as feedstock for the supercritical water gasification process and the simulation model was developed using Aspen plus (V11). The results show that higher temperature and lower biomass concentration favor production of hydrogen-rich gas while lower temperature and higher biomass concentration favor methane-rich gas production. Nannochloropsis sp. gave the highest lower heating value and also higher yield of $\mathrm{H}_{2}$ and $\mathrm{CH}_{4}$ was obtained when compared to Spirulina sp., and Scenedesmus obliquus microalgae. In terms of ranking order, Nannochloropsis $\mathrm{sp}>$ Scenedesmus obliquus > Spirulina sp. The findings showed that feedstock composition, temperature and biomass concentration has a great influence of the yield and composition of the product gas.

\section{CONFLICT OF INTEREST}

The authors declare no competing financial interest.

\section{ACKNOWLEDGMENT}

The authors thankfully acknowledge the financial support of the Durban University of Technology.

\section{REFERENCES}

[1] Onwudili JA, Lea-Langton AR, Ross AB, Williams PT. Catalytic hydrothermal gasification of algae for hydrogen production: composition of reaction products and potential for nutrient recycling. Bioresource technology. 2013;127:72-80. https://doi.org/10.1016/j.biortech.2012.10.020

[2] Mathimani T, Baldinelli A, Rajendran K, Prabakar D, Matheswaran M, Pieter van Leeuwen R, Pugazhendhi A. Review on cultivation and thermochemical conversion of microalgae to fuels and chemicals: Process evaluation and knowledge gaps. Journal of Cleaner Production. 2019;208:1053-1064. https://doi.org/10.1016/j.jclepro.2018.10.096

[3] Stucki S, Vogel F, Ludwig C, Haiduc AG, Brandenberger M. Catalytic gasification of algae in supercritical water for biofuel production and carbon capture. Energy \& Environmental Science. 2009;2:535-541. https://doi.org/10.1039/b819874h

[4] Miller A, Hendry D, Wilkinson N, Venkitasamy C, Jacoby W. Exploration of the gasification of Spirulina algae in supercritical water. Bioresource technology. 2012;119:41-47. https://doi.org/10.1016/j.biortech.2012.05.005

[5] Adnan MA, Susanto H, Binous H, Muraza O, Hossain MM. Feed compositions and gasification potential of several biomasses including a microalgae: A thermodynamic modeling approach. International journal of hydrogen energy. 2017;42:17009-17019. https://doi.org/10.1016/j.ijhydene.2017.05.187

[6] Adnan MA, Hossain MM. Co-gasification of Indonesian coal and microalgae-A thermodynamic study and performance evaluation. Chemical Engineering and Processing-Process Intensification. 2018 https://doi.org/10.1016/j.cep.2018.04.002

[7] Raheem A, Liu H, Ji G, Zhao M. Gasification of lipid-extracted microalgae biomass promoted by waste eggshell as $\mathrm{CaO}$ catalyst. Algal Research. 2019;42:101601. https://doi.org/10.1016/j.algal.2019.101601

[8] Atikah M, Harun R. Simulation and optimization of Chlorella vulgaris gasification using Aspen plus. Process Integration and Optimization for Sustainability. 2019;3:349-357. https://doi.org/10.1007/s41660-019-0080-7

[9] Adeniyi AG, Ighalo JO, Onifade DV, Adeoye SA. Modeling the valorization of poultry litter via thermochemical processing. Biofuels, Bioproducts and Biorefining. 2020;14:242-248. https://doi.org/10.1002/bbb.2056

[10] Fernandez-Lopez M, Pedroche J, Valverde J, Sanchez-Silva L. Simulation of the gasification of animal wastes in a dual gasifier using Aspen Plus®. Energy conversion and management. 2017;140:211-217. https://doi.org/10.1016/j.enconman.2017.03.008

[11] Borges FC, Xie Q, Min M, Muniz LAR, Farenzena M, Trierweiler JO, Chen P, Ruan R. Fast microwave-assisted pyrolysis of microalgae using microwave absorbent and HZSM-5 catalyst. Bioresource Technology. 2014;166:518-526. https://doi.org/10.1016/j.biortech.2014.05.100

[12] Chaiwong K, Kiatsiriroat T, Vorayos N, Thararax C. Study of bio-oil and bio-char production from algae by slow pyrolysis. Biomass and bioenergy. 2013;56:600-606. https://doi.org/10.1016/j.biombioe.2013.05.035

[13] Jiao J-L, Wang F, Duan P-G, Xu Y-P, Yan W-H. Catalytic hydrothermal gasification of microalgae for producing hydrogen and methane-rich gas. Energy Sources, Part A: Recovery, Utilization, and Environmental Effects. 2017;39:851-860. https://doi.org/10.1080/15567036.2016.1270375

[14] Hao X, Guo L, Mao X, Zhang X, Chen X. Hydrogen production from glucose used as a model compound of biomass gasified in supercritical water. International Journal of Hydrogen Energy. 2003;28:55-64. https://doi.org/10.1016/S0360-3199(02)00056-3

[15] Duan P-G, Li S-C, Jiao J-L, Wang F, Xu Y-P. Supercritical water gasification of microalgae over a two-component catalyst mixture. Science of the Total Environment. 2018;630:243-253. https://doi.org/10.1016/j.scitotenv.2018.02.226

[16] Chakinala AG, Brilman DWF, van Swaaij WPM, Kersten SRA. Catalytic and Non-catalytic Supercritical Water Gasification of Microalgae and Glycerol. Industrial \& Engineering Chemistry Research. 2010;49:1113-1122. 10.1021/ie9008293. 